\title{
Radial Variation in Selected Physical and Anatomical Properties Within and Between Trees of 31 Year Old Pinus caribaea (Morelet) Grown in Plantation in Nigeria
}

\author{
Adewunmi Omobolaji Adenaiya ${ }^{1 *}$, Olukayode Yekin Ogunsanwo ${ }^{1}$
}

(1) University of Ibadan, Faculty of Agriculture and Forestry, Department of Forest Resources Management, Ibadan, Nigeria

*Correspondence: e-mail: wumexrulz@yahoo.com

\begin{abstract}
Citation: ADENAIYA AO, OGUNSANWO OY 2016 Radial Variation in Selected Physical and Anatomical Properties Within and Between Trees of 31 Year Old Pinus caribaea (Morelet) Grown in Plantation in Nigeria. South-east Eur for 7 (1): 49-55. DOI: http://dx.doi.org/10.15177/seefor.16-07
\end{abstract}

Received: 19 Jan 2016; Revised: 8 Mar 2016; Accepted: 9 Mar 2016; Published online: 7 Apr 2016

\begin{abstract}
Background and Purpose: Variation in wood is a common phenomenon. Eliciting information on the pattern and extent of variation in wood properties is crucial to knowing the end use of wood species. This to a larger extent helps in the efficient and sustainable utilization of wood. Pinus caribaea has been internationally affirmed to be suitable for the manufacturing of pulp and paper. Since its introduction into Nigeria, the possibility for its use for pulp and paper has been grossly undermined because of the non-functional paper mills in Nigeria. Hence, the established plantations of the species in the country have gradually been exploited for timber. In order to ensure the efficient use of the species for structural purposes, it is therefore pertinent to understand the variation pattern in its anatomical and physical properties.

Materials and Methods: Five trees of 31 year old $P$. caribaea wood were harvested at Shasha Forest Reserve, South-West Nigeria. Bolts of $50 \mathrm{~cm}$ in length were obtained from each felled tree at breast height $(1.3 \mathrm{~m})$. Discs of $5 \mathrm{~cm}$ thickness were obtained from each bolt which were used for the anatomical investigation. The bolts were used for the investigation of the physical properties. The data generated were subjected to ANOVA and Regression Analysis.

Results: The results show that considerable differences exist in the anatomical properties among trees $(p<0.05)$. The physical properties show no marked difference among trees $(p>0.05)$. Both the physical and anatomical properties differ insignificantly within the tree ( $p>0.05)$. Tree's basic density, tracheid wall thickness and lumen diameter only explained $49 \%$ of the variation in the preservative absorption within the tree $\left(R^{2}=0.4884, P\right.$-value $\left.=0.053\right)$, re-emphasizing the major role played by bordered pits in the permeability of softwoods.

Conclusions: Due to the high preservative absorption observed using a non-pressure treatment, it is concluded that the species is very porous. Its porosity may pose a disadvantage when moisture absorption is concerned. Thus, it is recommended that the wood be properly treated in order to reduce its potentials in absorbing excessive moisture during service.
\end{abstract}

Keywords: tracheid, absorption, bordered pits, pit aspiration, density, preservative, structural application

\section{INTRODUCTION}

Globally, natural forests are rapidly on the decline. Due to the slow growth of natural forests and hence their inability to cater for the growing demand for wood and wood products, plantation forestry has therefore been practised over the years and as such, it has been the major supplier of wood for the wood industries. Industrial plantations of economic species in Nigeria were established in the 20th century, with concentrations of these plantations in the southern part of the country. The main exotic species under plantations in Nigeria include Tectona grandis, Gmelina arborea and Pinus caribaea, mainly due to their fast growth rate. 
Pinus caribaea (Carribean Pine) was primarily introduced to Nigeria for the production of long fibre pulp [1]. Currently, Nigeria imports pulp in order to manufacture her paper and paper products [2]. The inability of the pulp and paper industries in Nigeria to produce pulp, and consequently, depending on its importation led to the tree species established under plantations, which were initially intended to feed these pulp and paper mills outgrowing the stage of their suitability for pulp and paper. As a result, these species have been diverted to other uses. Pinus caribaea, even though a softwood species, has recently started gaining prominence for use as structural timber in Nigeria. As a fast growing species in Nigeria, it is therefore a promising species which can augment other structural timber species in the wake of increasing demand for solid wood in Nigeria. However, understanding its wood properties will provide a better insight into the ideal types of structural purposes it can be used for so as to ensure its efficient utilization.

Wood microstructure has long been recognised as an important tool in identifying the suitability of a wood species for a particular purpose [3] Also, it is unanimously agreed among researchers that wood density is a major factor affecting wood quality [4, 5]. Interestingly, within and between variability studies in wood properties of matured trees of $P$. caribaea in Nigeria are limited, given its value and the potentials it holds as a promising wood species in the country. Information on wood variation are essential for the improvement of properties which play crucial roles in its use as a raw material for both domestic and industrial uses [4]. Oluwadare [1] investigated the variation in some selected wood properties among different age classes of $P$. caribaea grown in Nigeria. Udoakpan [6] studied within tree variation in density, ring width and anisotropic shrinkage of Nigeria grown P. caribaea and observed little variability in the studied wood properties. However, within and between tree radial variation in the anatomical and physical properties of Nigerian grown $P$. caribaea within the same age class is unknown, which are also crucial determinants of wood quality [7].

Known to be a non-durable species, utilizing it for external structural applications therefore makes the treatment of $P$. caribaea wood with wood preservatives against biodeteriorating agents imperative in order to extend its service life, hence, promoting a more sustainable use of the wood. However, with several studies revealing a significant within-tree variation in wood properties [8], while variation in wood is expected to affect the uniformity in preservative uptake of the wood $[9,10]$ - an important index which determines the effectiveness of a wood preservative, it is therefore necessary to investigate the extent to which radial variation in the wood properties of $P$. caribaea will affect preservative absorption by its wood. Information gained from this will enable the development of an appropriate preservative treatment regime for this species in order to aid its efficient utilization.

In order to contribute to the existing knowledge on the variation in $P$. caribaea wood, this study aims to quantify radial variation in selected anatomical and physical properties within and among trees of $P$. caribaea with a view to advancing further knowledge on the species.

\section{MATERIALS AND METHODS}

\section{Wood samples and Site Characterization}

Wood samples used for this research were obtained from a 31 year old pine plantation grown in Shasha Forest Reserve, SouthWest Nigeria. The forest reserve is located on latitude $7^{\circ}$ and $7^{0} 30^{\prime} \mathrm{N}$ and longitude $4^{\circ}$ and $5^{\circ} E$ [11]. The total annual rainfall ranges from $887 \mathrm{~mm}$ to $2,180 \mathrm{~mm}$, and it has a minimum and maximum annual temperature of $19.5^{\circ} \mathrm{C}$ and $32.5^{\circ} \mathrm{C}$ respectively [12]. Five defectfree trees of $P$. caribaea with absence of reaction tendencies were harvested. Bolts of $50 \mathrm{~cm}$ in length were obtained from the breast height $(1.3 \mathrm{~m})$ of the trees. From each of these bolts, discs of $5 \mathrm{~cm}$ thickness were collected for use in the anatomical investigation. The breast height was chosen as the point of sampling along the tree bole because of the strong correlation of wood density with whole tree density $\left(r^{2}=0.99\right)$ at this point $[13,14]$. Thus, it is expected that results obtained from this chosen sample will reflect the wood properties for the whole tree since density is strongly correlated with all other wood properties.

\section{Determination of Basic Density}

Each of the remainder bolts ( $45 \mathrm{~cm}$ in length) were partitioned radially from pith to bark into three zones: inner wood (rings 1-10), middle wood (rings 11-20) and outer wood (rings 21-31) based on the number of rings. Ten wood samples of dimensions $6 \mathrm{~cm} \times 1.5$ $\mathrm{cm} \times 1.5 \mathrm{~cm}$ were obtained from each wood zone and oven-dried at $103^{\circ} \mathrm{C}$ for 18 hours. Basic density was estimated as the ratio of oven-dried weight of wood to green volume of wood [1].

\section{Determination of Tracheid Dimensions}

The discs were partitioned in a similar pattern as the one described above. From each of the discs, splints were obtained from each ring and macerated in equal volume (ratio 1:1) of $10 \%$ acetic acid and $30 \%$ hydrogen peroxide [15]. The macerated slivers were then washed; distilled water was then added after which they were shaken vigorously to separate the fibres. The suspension was mounted on a slide with the aid of a rubber teat, stained with safranin and 10 tracheids were measured in swollen condition [16], using the Rheichert visopan microscope for length $(\mathrm{mm})$, diameter $(\mu \mathrm{m})$, lumen width $(\mu \mathrm{m})$ and cell wall thickness $(\mu \mathrm{m})$. Two slides were prepared for each wood sample.

\section{Determination of Preservative Absorption}

The samples used in estimating the basic density for each partitioned wood zone, as described above, were subsequently treated by soaking for 24 hours in a preservative formulated from a mixture of castor oil (Ricinus communis) extracted mechanically from its seeds and kerosene (an organic solvent used as the diluent) in the ratio 3:7 using the volume dilution method [17]. Preservative absorption of the wood samples was determined by using the method employed by Olajuyigbe et al. [17]:

$$
\text { Absorption }=\frac{\left(10^{6} \cdot \mathrm{WPA}\right)}{(1000 \cdot \mathrm{V})}\left(\mathrm{kg} \cdot \mathrm{m}^{-3}\right)
$$

where WPA is weight of preservative absorbed $(\mathrm{kg})$, and $\mathrm{V}$ is volume of wood sample $\left(\mathrm{m}^{3}\right)$.

\section{Statistical analysis}

The data obtained were analyzed using descriptive statistics and two-way analysis of variance (ANOVA) in order to evaluate the variation in the wood species' anatomical and physical properties among trees (tree effect) and within tree (radial effect). A multivariate regression analysis was used to model the preservative absorption as a function of the basic density and anatomical properties investigated. During the model development process, predictor variables which contributed insignificantly to preservative absorption were eliminated. 


\section{RESULTS}

\section{Between-Tree Variation in Wood Properties}

The pattern of radial variation in the tracheid biometry and physical properties investigated among trees are presented graphically in Figures 1-6. The figures show no consistent pattern of variation from pith to bark in the physical and anatomical properties among the trees. The standard errors for each wood property among the trees greatly differ (Table 1 ), further indicating heterogeneity among the trees.

Values of wood properties for individual trees are presented in Table 1. The mean range of tracheid length is $1.85-2.68 \mathrm{~mm}$, with the wood having an average tracheid length of $2.31 \mathrm{~mm}$. Tracheid diameter ranged between 45.37-60.72 $\mu \mathrm{m}$, with an overall average of $53.25 \mu \mathrm{m}$. Mean values of $34.86 \mu \mathrm{m}$ and $9.2 \mu \mathrm{m}$ were recorded for tracheid lumen diameter and cell wall thickness respectively. However, it was observed that all the anatomical properties differed significantly $(p<0.05)$ among trees (Table 3$)$.
For the physical properties, basic wood density ranged between $413.85-536.95 \mathrm{~kg} \cdot \mathrm{m}^{-3}$, while preservative absorption of the wood ranged between 110.17-158.93 $\mathrm{kg} \cdot \mathrm{m}^{-3}$. Mean preservative absorption and basic density of the wood were $126.28 \mathrm{~kg} \cdot \mathrm{m}^{-3}$ and $500.41 \mathrm{kgm}^{-3}$ respectively. Both the wood basic density and preservative absorption were not statistically significant ( $p>0.05$ ) among trees (Table 3 ).

\section{Within-Tree Variation in Wood Properties}

The within-tree radial variation in the wood properties of $P$. caribaea from pith to bark is shown in Table 2 below. Tracheid length steadily increased from the core $(2.16 \mathrm{~mm})$ to the periphery $(2.45 \mathrm{~mm})$. Tracheid diameter and lumen width, as observed in this study decreased from the core outwards. However, an inconsistent pattern of variation was observed for the cell wall thickness, with a gradual increase from the core wood $(8.65$ $\mu \mathrm{m})$ to the middle wood $(9.54 \mu \mathrm{m})$, and then further declining in the outer wood $(9.38 \mu \mathrm{m})$. The physical properties investigated

TABLE 1. Physical and anatomical properties of $P$. caribaea wood

\begin{tabular}{|c|c|c|c|c|c|c|}
\hline \multirow{2}{*}{ Wood properties } & \multicolumn{5}{|c|}{ Tree No. } & \multirow{2}{*}{ Grand mean } \\
\hline & 1 & 2 & 3 & 4 & 5 & \\
\hline \multicolumn{7}{|l|}{ Tracheid length $(\mathrm{mm})$} \\
\hline Mean & 2.16 & 2.68 & 1.85 & 2.49 & 2.39 & 2.31 \\
\hline Standard error & 0.06 & 0.14 & 0.08 & 0.06 & 0.07 & \\
\hline \multicolumn{7}{|l|}{ Tracheid diameter $(\mu \mathrm{m})$} \\
\hline Mean & 58.92 & 60.72 & 45.37 & 47.85 & 53.21 & 53.25 \\
\hline Standard error & 1.17 & 1.62 & 1.3 & 0.96 & 0.98 & \\
\hline \multicolumn{7}{|l|}{ Tracheid lumen width $(\mu \mathrm{m})$} \\
\hline Mean & 41.99 & 39.79 & 31.46 & 28.51 & 32.33 & 34.86 \\
\hline Standard error & 0.99 & 2.19 & 1.08 & 0.88 & 0.81 & \\
\hline \multicolumn{7}{|l|}{ Cell wall thickness $(\mu \mathrm{m})$} \\
\hline Mean & 8.49 & 10.47 & 6.95 & 9.67 & 10.44 & 9.2 \\
\hline Standard error & 0.42 & 0.67 & 0.21 & 0.67 & 0.34 & \\
\hline \multicolumn{7}{|l|}{ Basic density $\left(\mathrm{kg} \cdot \mathrm{m}^{-3}\right)$} \\
\hline Mean & 413.85 & 510.93 & 526.98 & 513.34 & 536.95 & 500.41 \\
\hline Standard error & 11.23 & 23.95 & 11.55 & 12.39 & 20.04 & \\
\hline \multicolumn{7}{|l|}{ Absorption $\left(\mathrm{kg} \cdot \mathrm{m}^{-3}\right)$} \\
\hline Mean & 158.93 & 117.21 & 131.04 & 110.17 & 114.02 & 126.28 \\
\hline Standard error & 12.35 & 4.33 & 4.38 & 3.68 & 5.43 & \\
\hline
\end{tabular}

TABLE 2. Radial variation in wood properties of $P$. caribaea wood

\begin{tabular}{|c|c|c|c|}
\hline \multirow{2}{*}{ Wood properties } & \multicolumn{3}{|c|}{ Radial wood zones } \\
\hline & Core wood & Middle wood & Outer wood \\
\hline Tracheid length (mm) & 2.16 & 2.31 & 2.45 \\
\hline Tracheid diameter (mm) & 54.8 & 53.87 & 51.3 \\
\hline Tracheid lumen width (mm) & 37.53 & 34.78 & 32.55 \\
\hline Cell wall thickness (mm) & 8.65 & 9.54 & 9.38 \\
\hline Basic density $\left(\mathrm{kg} \cdot \mathrm{m}^{-3}\right)$ & 441.46 & 521.71 & 538.06 \\
\hline Absorption $\left(\mathrm{kg} \cdot \mathrm{m}^{-3}\right)$ & 119.16 & 119.21 & 140.46 \\
\hline
\end{tabular}


(wood basic density and preservative absorption) both showed a consistent increase from pith to bark. Within-tree differences observed for all the wood properties from pith to bark were however not statistically significant ( $p>0.05$ ) (Table 3).

\section{The Relationship Between Wood Properties and Pre- servative Absorption}

The model presented in Table 4 reveals the key variables that significantly influenced preservative absorption in the wood

TABLE 3. The analysis of variation among and within trees of P. caribaea (radial)

\begin{tabular}{|c|c|c|c|}
\hline Wood properties & df & Mean square & P-value \\
\hline \multicolumn{4}{|l|}{ Tracheid length } \\
\hline Trees & 4 & 0.398 & $0.038 *$ \\
\hline Radial wood zone & 2 & 0.242 & $0.134 n s$ \\
\hline Residual & 8 & 0.092 & \\
\hline Total & 14 & & \\
\hline \multicolumn{4}{|l|}{ Tracheid diameter } \\
\hline Trees & 4 & 136.778 & $0.001 *$ \\
\hline Radial wood zone & 2 & 15.942 & $0.24 \mathrm{~ns}$ \\
\hline Residual & 8 & 9.308 & \\
\hline Total & 14 & & \\
\hline \multicolumn{4}{|l|}{$\begin{array}{l}\text { Tracheid lumen } \\
\text { width }\end{array}$} \\
\hline Trees & 4 & 101.219 & $0.008^{*}$ \\
\hline Radial wood zone & 2 & 29.942 & $0.166 n s$ \\
\hline Residual & 8 & 13.193 & \\
\hline Total & 14 & & \\
\hline \multicolumn{4}{|l|}{ Cell wall thickness } \\
\hline Trees & 4 & 6.601 & $0.035^{*}$ \\
\hline Radial wood zone & 2 & 1.086 & $0.513 n s$ \\
\hline Residual & 8 & 1.493 & \\
\hline Total & 14 & & \\
\hline \multicolumn{4}{|l|}{ Basic density } \\
\hline Trees & 4 & 7358.781 & $0.41 \mathrm{~ns}$ \\
\hline Radial wood zone & 2 & 13367.556 & $0.193 n s$ \\
\hline Residual & 8 & 6556.949 & \\
\hline Total & 14 & & \\
\hline \multicolumn{4}{|l|}{ Absorption } \\
\hline Trees & 4 & 1185.692 & $0.541 \mathrm{~ns}$ \\
\hline Radial wood zone & 2 & 754.449 & $0.609 n s$ \\
\hline Residual & 8 & 1426.6 & \\
\hline Total & 14 & & \\
\hline
\end{tabular}

* - significant at $(p<0.05) ; n s$ - not significant at $(p>0.05)$ of $P$. caribaea. A positive relationship was observed between tracheid diameter and absorption. Wood density was positively related to preservative absorption, while an inverse relationship was observed between cell wall thickness and preservative absorption. From the model, tracheid diameter, wall thickness

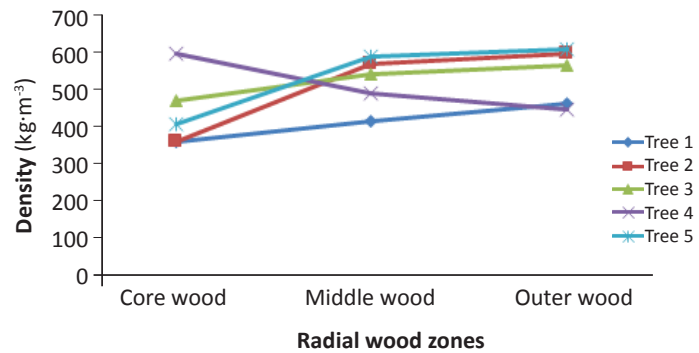

FIGURE 1. Radial variation in wood density among trees of P. caribaea

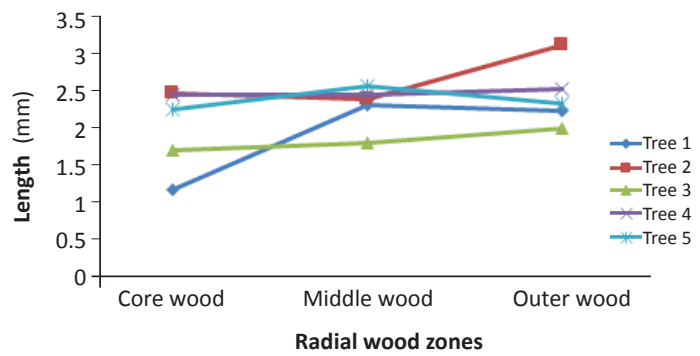

FIGURE 2. Radial variation in tracheid length among trees of P. caribaea

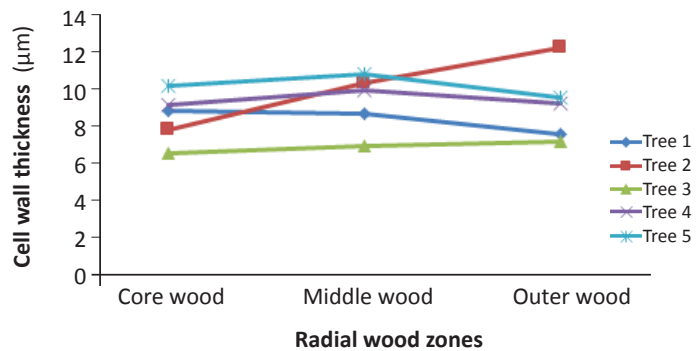

FIGURE 3. Radial variation in tracheid wall thickness among trees of $P$. caribaea

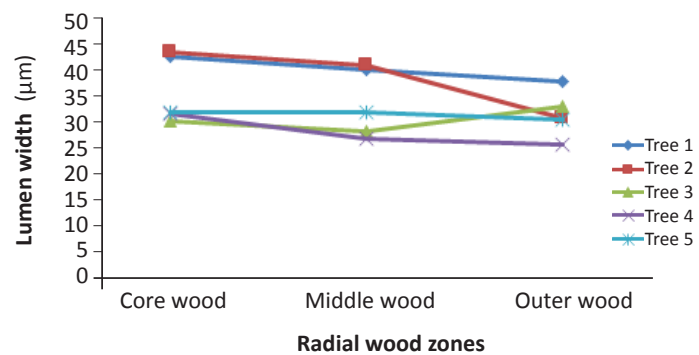

FIGURE 4. Radial variation in tracheid lumen width among trees of $P$. caribaea 


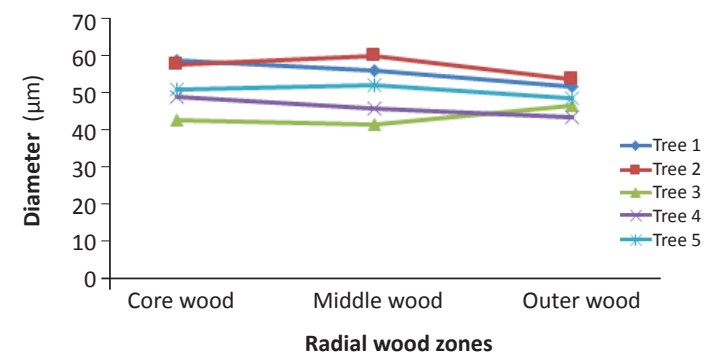

FIGURE 5. Radial variation in tracheid diameter among trees of $P$. caribaea

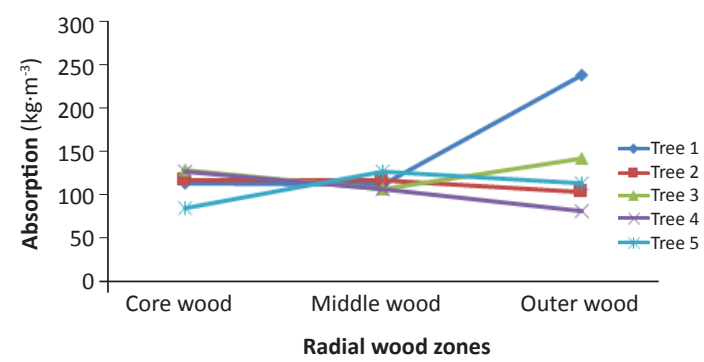

FIGURE 6. Radial variation in preservative absorption among trees of $P$. caribaea

TABLE 4. The relationship between wood properties and preservative absorption in $P$. caribaea wood

\begin{tabular}{lccc}
\hline \multicolumn{1}{c}{ Parameters } & Estimates & Std. Error & P-value \\
\hline Intercept & -3.09345 & 3.2219 & $0.36 \mathrm{~ns}$ \\
In Diameter & 1.11843 & 0.48454 & $0.04^{*}$ \\
Wall thickness & -0.11444 & 0.03698 & $0.01^{*}$ \\
In Density & 0.72866 & 0.32929 & $0.049^{*}$ \\
\hline
\end{tabular}

* - significant at $p<0.05 ; n s$ - not significant at $p>0.05$

and wood density only explained $49 \%$ of the variation in preservative absorption $\left(\mathrm{R}^{2}=0.488\right)$ by the wood of $P$. caribaea, with the developed model being significant at $94 \%$ probability level ( $p$-value=0.053).

\section{DISCUSSION}

Generally, this study shows that the anatomical properties of the wood varied significantly from the inter-tree comparison, while no marked differences were observed in the physical properties. Furthermore, the within-tree analysis revealed that individual trees were uniform in both their physical and anatomical properties. Ideally, anatomical properties of a particular wood should reflect its physical attributes [18, 19]; however, this is in contrast to the findings of this study. The non-association between both wood properties (anatomical and physical) among the trees suggests that differences in other anatomical properties and extrinsic factors such as extractive content, number and distribution of resin canals, earlywood/ latewood ratio within rings, etc which were not examined in this study may have contributed greatly to the differing variation patterns between the anatomical and physical properties observed among the $P$. caribaea trees $[18,19]$. The haphazard pattern of variation observed among trees for each wood property may be a result of the differences in the genotype of individual trees [20]. Nonetheless, the noticeable between-tree variation observed in the anatomical properties on the other hand may prove advantageous in tree breeding programmes, giving way for future improvement on its anatomical attributes.

The anatomical features investigated show a mixed result in comparison with existing literature. The radial pattern of variation in anatomical features has been extensively reported by several studies $[14,16,21]$. While the mean values obtained in this study for tracheid diameter and cell wall thickness were consistent with the results reported by Oluwadare [1], tracheid length and lumen width were, on the other hand, considerably low compared to his findings. The difference observed in the lumen width may possibly be due to differences in site conditions, silvicultural treatments, tree age, or tree genetic make-up [14, 18, 22]. The wood tracheid length, apart from being considerably lesser to that reported by Oluwadare [1], is also low when compared to some other pine species [14, 23] and to the average tracheid lengths of 3-5 mm generally reported for softwoods [24]. Possible reasons for this outcome may be due to erroneous measurement of some broken tracheids or, perhaps, due to the reduced number of sampled tracheids in the study when compared to other similar studies [e.g. 1], thus making the sampled tracheids poor representatives of the entire tracheid population of the trees.

The increasing trend from pith to bark observed for the physical properties is consistent with that reported for some softwood species $[16,18,19]$. The mean basic density for the wood observed in this study $\left(500.41 \mathrm{~kg} \cdot \mathrm{m}^{-3}\right)$ is similar to that reported by Oluwadare [1] and Hashemi and Kord [6] for $P$. caribaea grown in Nigeria, although a little bit higher than that reported in Sri Lanka [25]. This contrasting result with that obtained in Sri Lanka may be due to differences in tree age or silvicultural treatments $[22,26]$. The increase in preservative absorption from pith to bark can be explained by the reduced number of aspirated pits from pith to bark, consequent of the increasing proportion of latewood percentage from the inner wood to the outer wood [27]

Apparently, the moderate basic density of the wood shows that it will be suitable for light construction works. However, the relatively uniform density of the wood observed in this study makes it ideal for veneer production by peeling or slicing [28]. More so, the preservative absorption values of the wood indicate that sufficient absorption levels can be obtained through treatment by non-pressure methods rather than the use of the higher energy-consuming pressure treatments. It is worthy to note that even though the average tracheid lumen width and basic density are comparable to some other pine species [e.g. 14], it may pose a problem in joinery works due to the high preservative absorption observed in this study. The implication of this, by extension, is that the wood will permit excessive moisture absorption during fluctuations in atmospheric moisture which may result in high swelling and shrinkage. 
The observed relationship between the wood properties and preservative absorption was weak due to the low predictive power of the wood properties. The positive relationship observed for both diameter and density with preservative absorption implies that wider tracheids and thick-walled tracheids with fewer aspirated pits enhanced absorption. This finding further reinforces the assertion that bordered pits play a prominent role in the flow of liquids in softwoods [27, 29]. Nonetheless, the observed positive relationship between density and absorption in this study is in contrast with observations of Ahmed et al. [30]. This disparity possibly is as a result of the wood type since permeability in hardwoods is primarily determined by wider vessel lumen and, by extension, a lower wood density. The inverse relationship between wall thickness and preservative absorption suggests that higher pressure is needed to achieve better preservative penetration into the tracheid cell walls, consequent of the type of preservative treatment method employed in this study. This observation however strongly suggests that radial variation in earlywood/latewood proportion significantly influenced absorption given that pit aspiration, and hence lateral fluid permeability within the wood along the radial direction was quite pronounced.

\section{CONCLUSION}

It can be concluded from this study that inter-tree variation in the anatomical properties was considerable while the trees exhibited uniformity in their physical properties. Within-tree variation on the other hand was insignificant. Interestingly, the wood can be described as being very porous, which is evident from the high preservative absorption recorded under a nonpressure method of treatment. This shows that the wood does not belong to the group of refractive wood species, since most softwoods are observed to be due to the pit aspiration phenomena. While the easy treatability of the wood might be an advantage, the possibility of absorbing excessive moisture which can result into pronounced wood movement needs to be addressed through proper treatments to reduce its moisture absorption capacity and thus, to improve its dimensional stability. Furthermore, this study clearly affirms that bordered pits largely determine permeability in softwoods. Although a high preservative absorption was observed, the depth of penetration and uniformity of the preservative absorption may largely be impaired by the extent of pit aspiration in the wood.

\section{REFERENCES}

1. OLUWADARE AO 2007 Wood properties and selection for rotation length in Caribbean pine (Pinus caribaea Morelet) grown in Afaka, Nigeria. American-Eurasian J Agric and Environ Sci 2 (4): 359-363

2. OGUNWUSI AA, ONWUALU AP 2013 Impact of privatization of primary pulp and paper mills on performance of the pulp and paper sector in Nigeria. Developing Country Studies 3 (7): 109-119

3. OGUNSANWO OY 2006 Variations in wood anatomical characteristics of Nigerian grown Triplochiton scleroxylon and their relationships with selected mechanical properties. J App Sci Eng Technol 6 (2): 68-75. DOI: http://dx.doi.org/10.4314/ jaset.v6i2.38312

4. PANSHIN AJ, DE ZEEUW C 1980 Textbook of Wood Technology, 4th edition. McGraw-Hill, New York, USA, $722 \mathrm{p}$

5. JSYKE T, MÄKINEN H, SARANPÄÄ P 2008 Wood density within Norway spruce stems. Silva Fenn 42 (3): 439-455. DOI: http:// dx.doi.org/10.14214/sf.248

6. UDOAKPAN UI 2013 An evaluation of wood properties of Pinus caribaea (Morelet) in Oluwa forest reserve, Ondo State, Nigeria. Ethiopian J Environ Stud Manage 6 (2): 159-169. DOI: http://dx.doi.org/10.4314/ejesm.v6i2.6

7. LEI H, MILOTA MR, GARTNER BL 1996 Between- and withintree variation in the anatomy and specific gravity of wood in Oregon white oak (Quercus garryana Dougl.). IAWA J 17 (4): 445-461. DOI: http://dx.doi.org/10.1163/2294193290000642

8. ZOBEL BJ, VAN BUIJTENEN JP 1989 Wood variation: Its causes and control. Springer-Verlag, Berlin, Heidelberg, New York. 363 p. DOI: http://dx.doi.org/10.1007/978-3-642-74069-5

9. NARKUS F 1989 Preservative uptake - An expression of wood impregnation when using cell-saturating pressure treatment. Holztechnologie 30 (5): 270-276

10. KAZEMI SM, HOSINZADEH A, REZAII MB 2006 The effect of woody and non-woody plants extractives on microbial resistance of non-durable species. The International Research Group On Wood Preservation. Paper for the 37th Annual Meeting, Tromso, Norway, pp18-22
11. AMUSA TO, JIMOH SO, AZEEZ IO, AWODOYIN RO, KAREEM I 2014 Stock density and fruit yield of African walnut in tropical lowland rainforests of Southwest Nigeria. J Trop For Environ 4 (2): 73-81

12. JIMOH SO 2002 A multiple use planning model for tropical rain forests: The case of Sasha Forest Reserve, Nigeria. PhD thesis, University of Ibadan, Faculty of Agriculture and Forestry, Ibadan, Nigeria, $248 \mathrm{p}$

13. DORAN J, BUSH D, PAGE T, GLENCROSS K, SETHY M, VIJI I 2012 Variation in growth traits and wood density in whitewood (Endospermum medullosum): a major timber species in Vanuatu. Int For Rev 14 (4): 476-485. DOI: http://dx.doi. org/10.1505/146554812804715946

14. KIAEI M, SADEGH AN, MOYA R 2013 Site variation of tracheidfeatures and static bending properties in Pinus eldarica wood. Cell Chem Technol 47 (1-2): 49-59

15. FRANKLIN GL 1945 Preparation of thin selection of synthetic resins and wood-resins composites and a new macerating method for wood. Nature 155: 3924-3951. DOI: http:// dx.doi.org/10.1038/155051a0

16. HASHEMI SKH, KORD B 2011 Variation of within-stem biometrical and physical property indices of wood from Cupressus sempervirens L. BioResources 6 (2): 1843-1857

17. OLAJUYIGBE SO, OGUNSANWO OY, ADEGEYE AO 2010 Compressive strength in heartwood extract of Teak (HWE) treated hardwoods after exposure to white rot attack. Int J Biol Chem Sci 4 (3): 571-578. DOI: http://dx.doi.org/10.4314/ iibcs.v4i3.60453

18. LARSON PR, KRETSCHMANN DE, CLARK A, ISEBRANDS JG 2001 Formation and properties of juvenile wood in southern pines: a synopsis. U.S Department of Agriculture, Forest Service, Forest Products Laboratory, Madison, WI, USA, $42 \mathrm{p}$

19. PAVLOVICS G, DOLACIS J, ANTONS A, CIRULE D 2010 Relationship between the anatomical structure elements and physical properties in the trunk transverse and longitudinal direction for wood of Norway spruce (Picea abies (L.) Karst.) growing in Latvia. For Wood Technol 72: 124-128. 
20. GARTNER BL, LEI H, MILOTA MR 1997 Variation in the anatomy and specific gravity of wood within and between trees of Red Alder (Alnus rubra Bong). Wood Fibre Sci 29 (1): $10-20$

21. KIAEI M 2010 Anatomical, physical, and mechanical properties of eldar pine (Pinus eldarica Medw.) grown in the Kelardasht region. Turk J Agric For 35 (1): 31-42. DOI: http:// dx.doi.org/10.3906/tar-1001-552.

22. ZOBEL BJ, THORBJORNSEN E, HENSON F 1960 Geographic, site and individual tree variation in wood properties of loblolly pine. Silvae Genet 9 (6): 149-158

23. TAYLOR FW, MOORE JS 1981 A comparison of earlywood and latewood tracheid lengths in loblolly pine. Wood Fiber Sci 13: $159-165$

24. NOAH AS 2009 Fundamentals of pulp and paper manufacture. Fasco Publisher, Ibadan, Nigeria, $181 \mathrm{p}$

25. RUWANPATHIRANAL ND, AMARASEKERA HS, DE SILVA MP 1996 Variation of Pinus caribaea Wood Density with Height in Tree and Distance from Pith in Different Site Classes. In: Amarasekera HS, Ranasingile DMSHK, Finlayson W (eds) Management and Sustainable Utilization of Forest Resources, Proceedings of the Second Annual Forestry Symposium, Sri Lanka, 6-7 December 1996. Department of Forestry and Environmental Science, University of Sri Jayewardenepura, Sri Lanka, pp 49-57
26. ZOBEL B 1992 Silvicultural effects on wood properties. Piracicaba 2: 31-38

27. USTA I, HALE MD 2006 Comparison of the bordered pits of two species of spruce (Pinaceae) in a green and kiln-dried condition and their effects on fluid flow in the stem wood in relation to wood preservation. Forestry 79 (4): 467-475. DOI: http://dx.doi.org/10.1093/forestry/cpl011.

28. JOZSA LA, MIDDLETON GR 1994 A discussion of wood quality attributes and their practical implications. Forintek Canada Corp, Vancouver, Canada, $42 \mathrm{p}$

29. LEHRINGER C, RICHTER K, SCHWARZE FWMR, MILITZ H 2009 A review on promising approaches for liquid permeability improvement in softwoods. Wood Fiber Sci 41 (4): 373-385.

30. AHMED SA, CHUN SK, MILLER RB, CHONG SH, KIM AJ 2011 Liquid penetration in different cells of two hardwood species. J Wood Sci 57 (3):179-188. DOI: http://dx.doi.org/10.1007/ $\underline{\mathrm{s} 10086-010-1168-4}$ 
